\title{
Futsal Field Management Information System Based on Android in 212 Galuh Mas Karawang
}

\author{
Eko Pramono ${ }^{1}$ \\ Computer science \\ Faculty of Engineering and Informatics \\ Bina Sarana Informatika University \\ Indonesia \\ eko.eop@bsi.ac.id
}

\author{
Saepul Aripiyanto ${ }^{2}$ \\ Information System \\ Faculty of Engineering and Computer Science \\ Universitas Buana Perjuangan \\ Karawang, Indonesia \\ Saepularipiyanto@ubpkarawang.ac.id
}

\author{
April Lia Hananto ${ }^{3}$ \\ School of Computing \\ Faculty of Engineering \\ University Teknologi \\ Malaysia \\ Hananto1983@graduate.utm.my
}

\begin{abstract}
This futsal field booking application is used to make it easier for tenants to know the empty futsal court schedule, to provide convenience in the process of renting a futsal field schedule without having to come directly to the futsal venue. Making this application is done by the System Development Life Cycle Method. This application is implemented with the Codeigniter framework, PHP programming language, MySQL database as a data storage medium and testing methods using black box testing. As for the futsal field schedule rental uses Gammu and modem as media. This application can be used by 3 users, namely admin, provider and tenant. Admin can do provider approval. Providers can process field data, rental rates, tenants, bookings, payment confirmations, galleries and providers. Tenants can book via Mobile and see available field schedule information, activation and payment confirmation.
\end{abstract}

Keywords: Booking, Futsal Place, Sldc, Java, Android Studio

Abstrak- Aplikasi pemesanan lapangan futsal ini digunakan untuk memudahkan penyewa mengetahui jadwal lapangan futsal yang kosong, untuk memberikan kemudahan dalam melakukan proses penyewaan jadwal lapangan futsal tanpa harus datang langsung ke tempat futsal. Pembuatan aplikasi ini dilakukan dengan Metode System Development Life Cycle (SDLC). Aplikasi ini di implementasikan dengan framework Codeigniter, bahasa pemograman PHP, database MySQL sebagai media penyimpanan data dan metode pengujian menggunakan black box testing. Sedangkan untuk SMS gateway penyewaan jadwal lapangan futsal menggunakan Gammu dan modem sebagai media. Aplikasi ini dapat digunakan oleh 3 pengguna, yaitu admin, penyedia dan penyewa. Admin dapat melakukan approval penyedia. Penyedia dapat olah data lapangan, harga sewa, penyewa, booking, konfirmasi pembayaran, gallery dan penyedia. Penyewa dapat melakukan bookingan via Mobile dan melihat informasi jadwal lapangan yang available, aktivasi dan konfirmasi pembayaran.

Kata Kunci: Pemesanan, Tempat Futsal, Sdlc, Java, Android Studio

\section{INTRODUCTION}

Technological knowledge is an asset that is currently developing rapidly, the development of technology is no longer a matter of years, months, or days, but also hours and seconds, especially about information technology as well as communication supported by electronic devices. The emergence of various versions of communication science also supports the advancement of information technology science, such as ios android and frameworks, but now android is a new science that has just emerged but has changed a lot. Ordering the futsal field is a promising endeavor. it has been widely applied in almost all cities having a futsal field rental business [1].

However, not all businesses are the same quality or weight, with the service process in making field bookings to transactions, for example, Futsal 212 which is located in Karawang district in this futsal field business has been running for quite a long time with a strategic location but at The booking and transaction processes in futsal still use manuals which hinder the progress of the business [2].

The futsal field ordering system is quite troublesome for tenants and members because it is still conventional. It becomes less efficient in terms of time, energy, and costs because users have to go directly to every futsal field location to check the futsal field orders and futsal shoes orders. Based on these constraints, a system with. Android-Based Futsal Field Management Application in [3].

This validation is precise for field calendar problems and futsal field reservations and futsal shoes. Android applications are easier to access. Android can be accessed from anywhere and anywhere as long as there is an internet network or internet connection. This futsal mobile application makes it easy for tenants to see the field schedule and order futsal shoes, this order is according to a predetermined time [4].

\section{METHODS}

\section{A. Application Concept Method}

The research method used is the SDLC (System Development Life Cycle) method. It consists of stages in an 
activity that runs in one direction from the start to the end of the project for system design and application. [5]. The following is Figure 2.1 Method of System Development Life Cycle

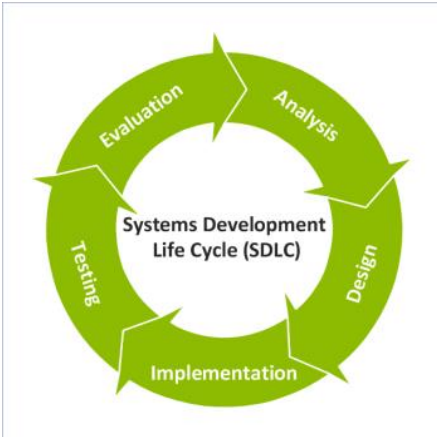

Figure 2.1 Life Cycle Development System Method

\section{B. Research Framework}

The research framework is a diagram that outlines the logical flow of a study, as shown in the figure below. [6] The following is Figure 2.2 Research Framework

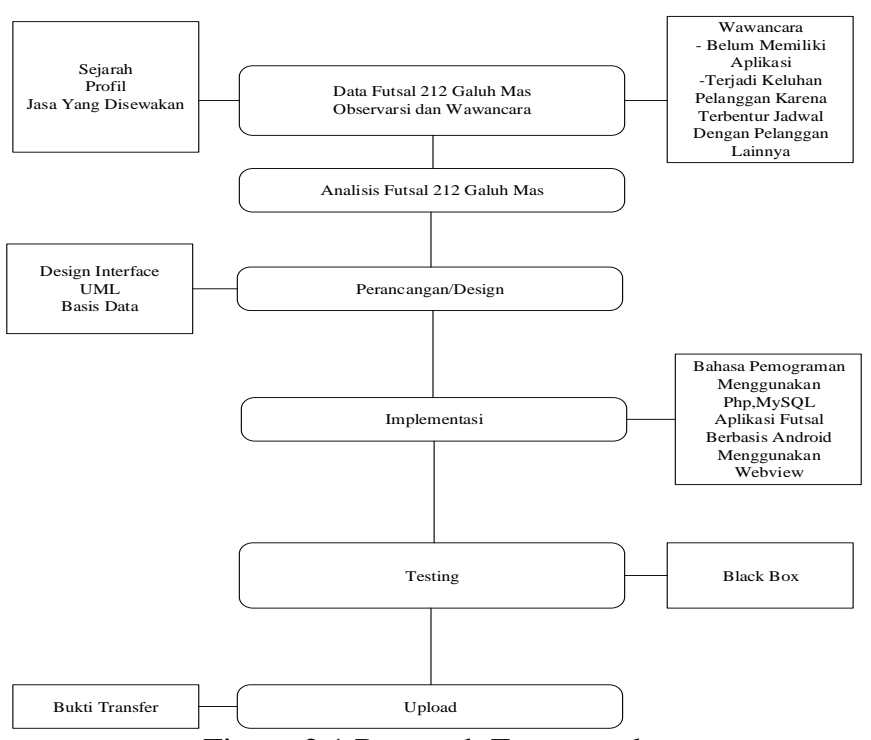

Figure 2.1 Research Framework

1. Futsal Data

A. Interview

In this interview, he held a dialogue with the management of Futsal 212 Galuh Mas Karawang. Aim to know the process of ordering the futsal field, so that it becomes a system [7].

B. Observation

The purpose of this observation is to observe the place of activity to get the information needed by the observer, by visiting the object of research directly [8].

C. Literature Study

Looking for theoretical references related to research topics raised by theories getting from several literary sources can be in the form of journal books, theses, and the internet [9].
2. Planning \& Design

A. UML (Unified Modeling Language)

The design of this system is a variety of designs such as Use Case Diagrams, Activity Diagrams, Class Diagrams, and Sequence Diagrams, [10].

B. Interface

The interface design uses the pencil application, there are two designs for this interface, namely the admin website design and the Android design, for the design as needed [11].

C. Database

This database is used to store data on the website, the database uses PHPMyAdmin [12].

3. Manufacturing Process

The process of making this system mainly analyzes the system that is currently running on futsal 212 and performs data retrieval according to the system's needs. The design of this system uses Star Unified Modeling Language (UML), such as admin data use case diagrams, admin data management activity diagrams, Admin Data Class Diagrams, Admin Data Sequence Diagrams. For user interface design using the pencil website admin and android applications. The Android implementation uses a web view where this review from the website continues to host the website and convert to android, then download the converted application from the website to android and install the application on the android. [13].

4. Testing

This test uses Blackbox in an android based futsal field management application test. [14].

5. Upload

This upload uses Infinityfree hosting to get access to the internet via an android mobile [15].

\section{RESULTS AND DISCUSSION}

Information about the futsal field reservation system still uses conventional or comes directly to the futsal location. This is intended so that this system that will be established can be applied properly and optimally and helps in making reports to support better information delivery by looking at the deficiencies and weaknesses of the old system.

The Current System In Futsal 212 Galuh Mas Karawang

1. Tenants or members of the futsal field must come directly to their futsal court to ask about the empty field schedule [16].

2. Admin checks the empty field schedule [17].

3. Admin records field orders and provides receipt of bookings to tenants or members [18].

4. The tenant or futsal member directly pays down payment as a guarantee that the rental of the field will be according to the predetermined schedule [19].

5. Admin records field schedules booked by tenants or members [20]. 


\section{A. Ongoing System Analysis}

The system analysis that is currently running is described systemically with the activities that occur in a futsal field ordering process and a deposit for ordering the Futsal 212 Galuh Mas Karawang field. The following is the flowchart of the futsal field reservation system that is currently running in futsal 212 Galuh Mas Karawang [21].

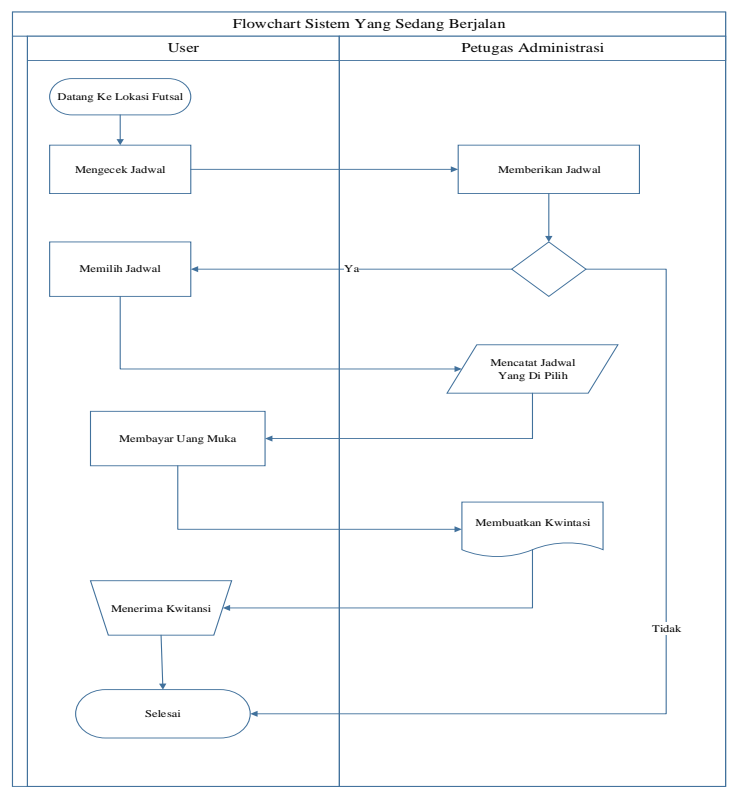

Figure 3.1 Current System

B. Proposed System

Based on the results of the system analysis that is currently running above, the authors propose a system design and application based on websites and androids on futsal 212 Galuh Mas Karawang, while the results of the system analysis that the author developed are described in more detail in the 2 flowcharts below. [22].

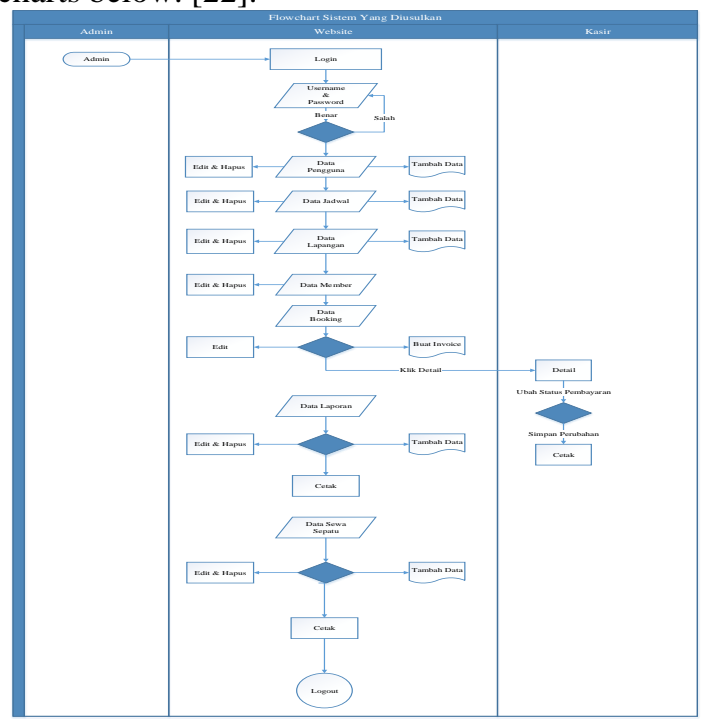

Figure 3.2 Proposed System

\section{Website Admin Design}

Design is the initial procedure of making a system or application to be made, where can be seen the processes required in making a system or application. While the design procedure made is a stage to improve or increase work efficiency, the system design stage is described as design to build a system or application and configure software and hardware components to produce a good application, the designed application becomes one component. [23].

1. Use Case Diagram Managing Admin Data

This use case is used to manage data which in this management is to make it easier for admins to input user data, member data, futsal shoe rental data, booking data, schedule data, field data, report data, payment data. Furthermore, by conducting an assessment of the admin data design. [24].

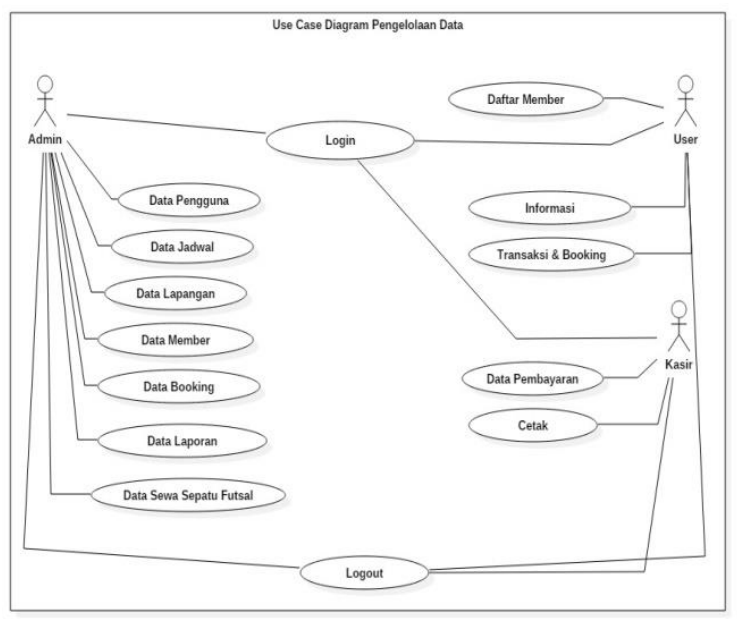

Figure 3.3 Use Case Diagram

2. Admin Data Activity Diagram

Use case diagram login workflow to the admin website to manage data through the activity diagram as follows. Starting from the admin website login, the admin fills in the login form by using the username and password to access the admin website. Can input data and confirm who book the field and rent shoes and make payments [25].

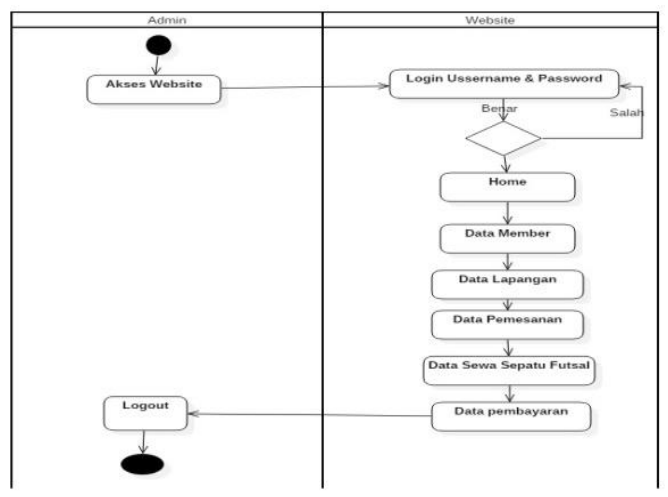

Figure 3.4 Activity Diagram

\section{Class Diagram Admin}

The class diagram is an important element in objectoriented systems, class describes a system building block. Claas diagrams have features that model multiplicity, information, markers, polymorphism, and 
other characteristics, some of which are listed in this system are concerned with designing an android-based futsal field management application [26].

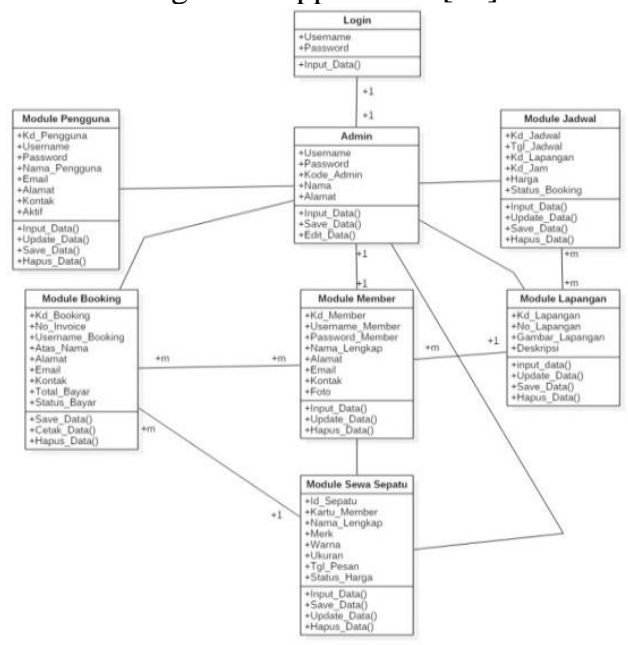

Figure. 3.5 Admin Class Diagram

4. Sequence Diagram of Admin Data

Sequence diagrams are used to describe the interactions between objects in sequential time. But basically, sequence diagrams are used in the object model abstraction layer [27].

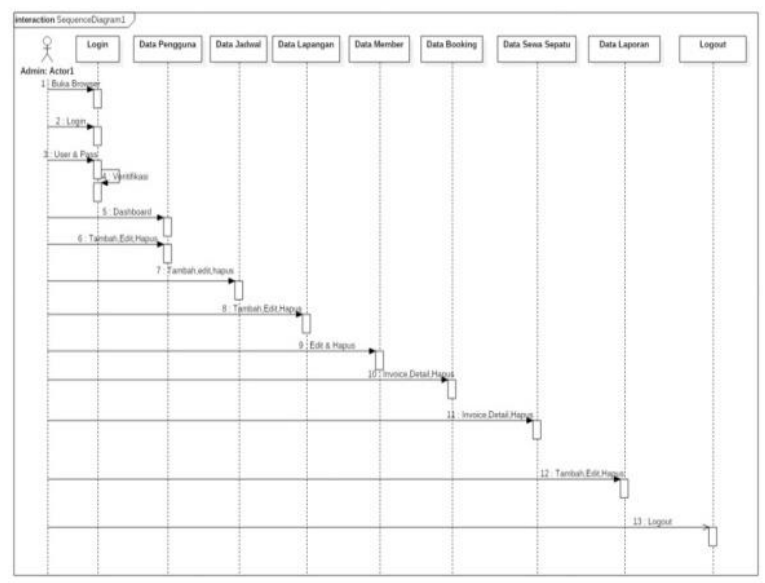

Figure 3.6 Admin Data Sequence Diagram

D. User Interface Website

On this website, to manage data in the futsal area, especially managing futsal field bookings or futsal field reservations and providing futsal shoes rental, namely by ordering online via an android-based mobile futsal application There are several menus on the admin website, namely. Member Data, Field Data, Order Data, Futsal Shoes Data, Payment, and Logout Data [28].

\section{A. Admin Login Display}

This login screen enters the username and password to access the admin website, if the username is wrong or the password is wrong, return to the database to match the database. Here is a login image to the admin website [29].

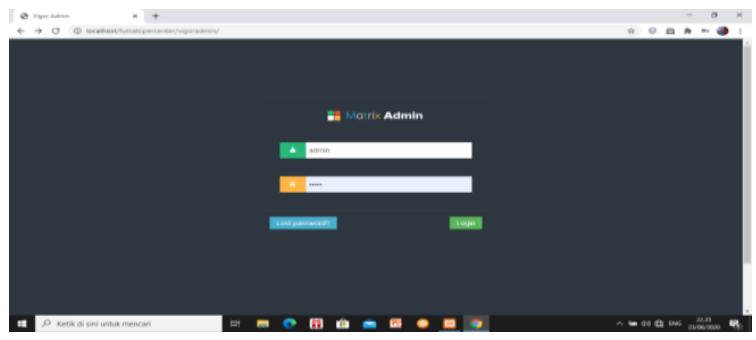

Figure 3.7 Login Page

A. Website Admin Homepage

The home page of this website has several menus for managing it such as member data, field data, ordering data, futsal rental data, payment, and logout data, these five menus admin has the right to delete and edit them in the admin area who manages these menus in [30]

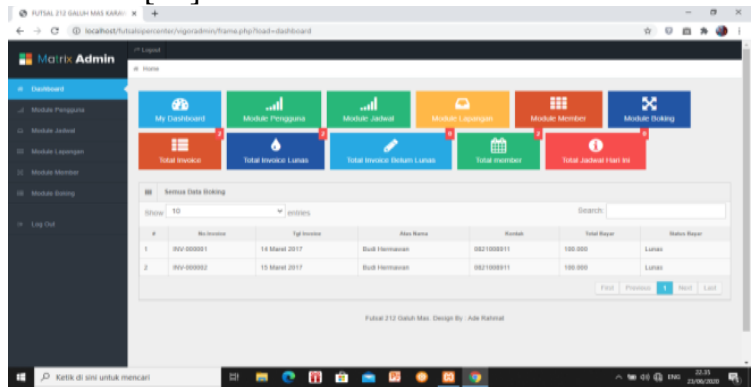

Figure 3.8 Home Page

B. User Module page

This module user page admin can delete user data that is no longer active and edit wrong user data, this user module gets a card from the futsal place, first fill in the registration form, namely in the Futsal 212 Galuh Mas application Karawang. The following is an image of the Admin Website User Module Page [31].

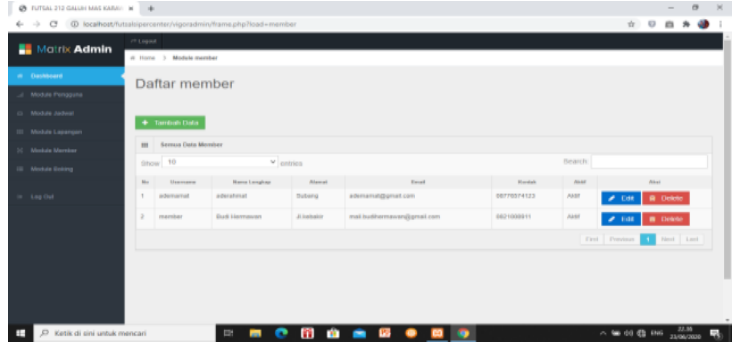

Figure 3.9 User Module Page

C. Field Data page

The Futsal Field Data admin page can add new field data or edit the futsal field that has been used by tenants or members, and delete futsal fields that are not fit for use or are damaged [32].

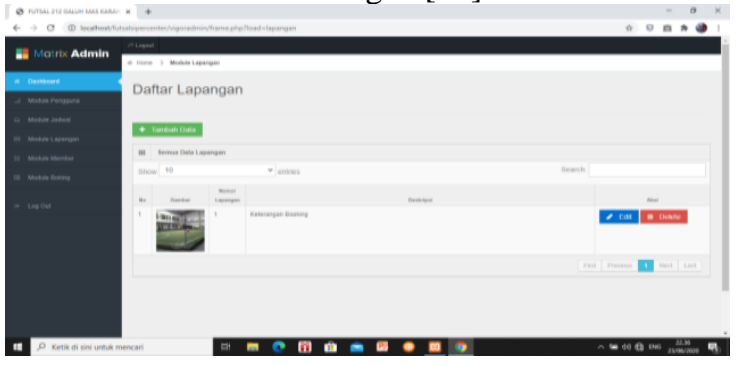


Figure 3.10 Field Data Page

D. Schedule List Module page

The Module page lists the Futsal Field schedule, is a futsal field that is already in use or is new to add empty booking hours and edit the field. The following is a picture of the update page \& add the futsal field schedule module [33].

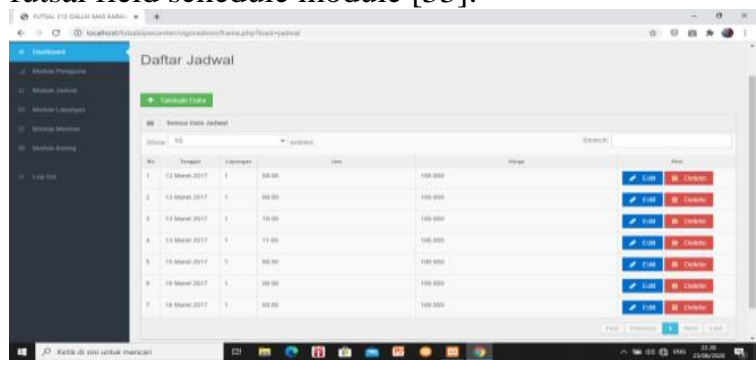

Gambar 3.11 Halaman Daftar Jadwal

E. Field List Module page

This Futsal Field List page is the admin managing, such as confirming or canceling confirmation or deleting the schedule list data page, the admin can cancel the confirmation if the tenant or member does not come and is replaced by another. The following is a picture of the module page listing the futsal court on the admin website [34]

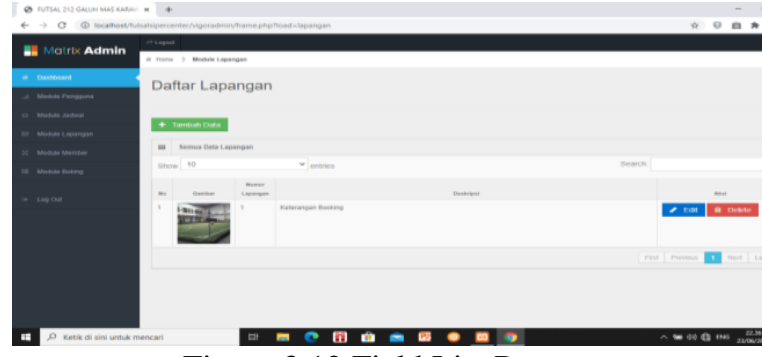

Figure 3.12 Field List Page

F. Member Module page

This Member Module page is to find out who registers as a futsal member, through an androidbased futsal application, to make it easier for tenants or people who want to register as futsal members. The following is a picture of a futsal shoe rental data page [35].

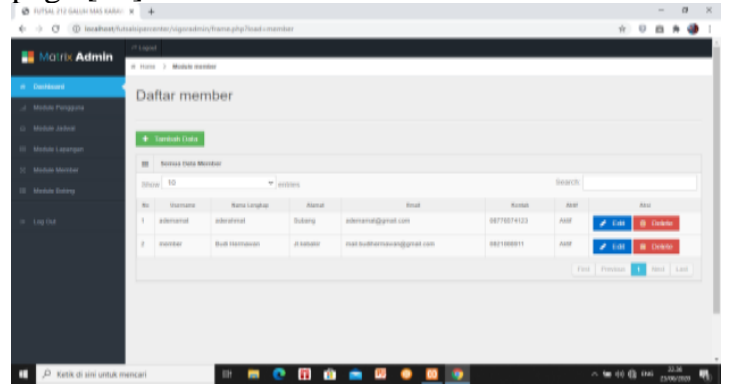

Figure 3.13 Member Module page

G. Booking List Module page

This Booking List Module page is to find out orders or bookings for futsal fields that have been booked by tenants or futsal members, and the admin gets edits and deletes if they don't or are canceled by the tenants. The following is a picture of the module for the booking list for futsal 212 Galuh Mas Karawang [36].

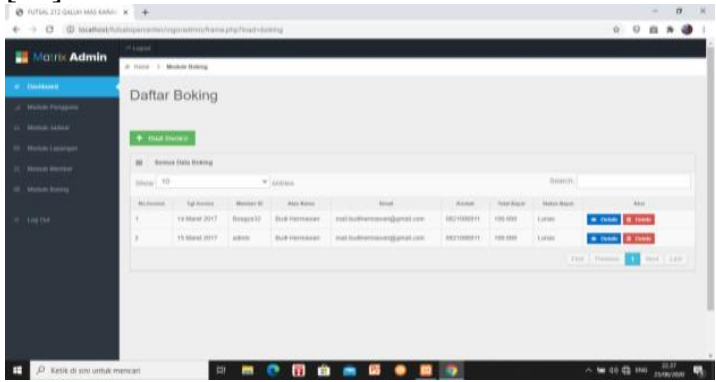

Figure 3.14 Module page of Field Booking List

H. Logout page

This logout page is to log out of the admin website, after logging in from the beginning of the admin website, filling in the username and password, and pressing the login button to access the admin website. The following is a logout image on the admin website [37].

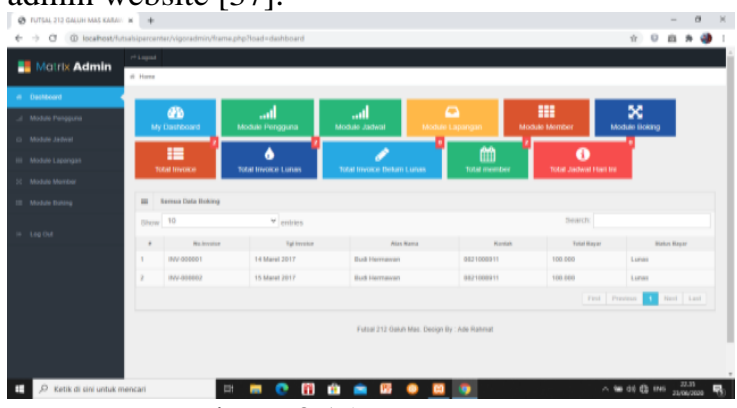

Figure 3.15 Logout page

I. Android application

The Futsal Super Mobile application, before accessing the futsal super application, you must register or register to fill in your bio and get a username and password, to access the futsal super mobile application [38].

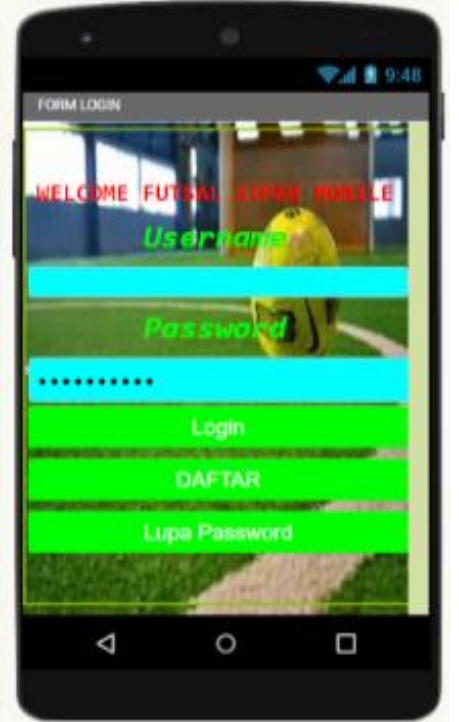

Figure 3.16 Futsal Application Based on Android 


\section{CONCLUSION}

From the results of field research and the process of making android and admin websites, the authors conclude the following:

1. Customers can access information on the futsal field without having to go to the futsal location in the application that has been provided.

2. Creating an application that features a futsal court rental that can be accessed anytime and anywhere via Android.

\section{REFERENCES}

[1] Agustian, A., Rahayu, S., \& Nurlani, L. (2018). Aplikasi E-Futsal Dengan Metode Mobile-Gis Dan Gps Berbasis Android.

[2] Ardiansah, Y., \& Hartanto, A. D. (2015). Perancangan Dan Pembuatan Aplikasi Ready For Battle Futsal Berbasis Android. Jurnal Ilmiah, 16(1), 63-68.

[3] Baenil Huda \& Bayu Priatna, (2020). Penggunaan Aplikasi Content Manajement System (Cms) Untuk Pengembangan Bisnis Berbasis E-Commers Dio. Revista Brasileira De Ergonomia, 9(2), 10.

[4] Ekasari, M. H., Diana, D., \& Saefudin, M. (2020). Aplikasi Smartphone Gis (Geografik Information System) Pencarian Lapangan Futsal Daerah Tangerang Berbasis Android.

[5] Ewing, S. A., Panciera, R. J., Mathew, J. S., Novelli, F. Z., Biológica, R., Bocas, D., Aguiar, D. M. (2016). Analisa Dan Perancangan Sistem Informasi Parkir Di Universitas Muria Kudus.

[6] Hakim, L., Juita, H. R., \& Pratama, F. (2019). Rancang Bangun Aplkasi Pemesanan Lapangan Futsal Berbasis
Web Mobile Di Mega Futsal F.Trikoyo Kecamatan Tugumulyo Kabupaten Musi Rawas.

[7] Istiana, Y., \& Iriani, S. (2015). Aplikasi Pendataan Siswa Guru Dan Karyawan Pada Pimpinan Daerah Aisyiyah Kabupaten Pacitan.

[8] Köksal, Y., \& Penez, S. (2015). Aplikasi Membership Di Lapangan Futsal Moriz Berbasis Android Artikel.

[9] Ratnasari, D., Hadi, H. F., \& Budiarto, J. (2018). Rancang Bangun Aplikasi Penyewaan Lapangan Futsal Berbasis Android.

[10] Tukino, Shofia Hilabi, S., \& Romadhon, H. (2020). Production Raw Material Inventory Control Information System At Pt. Siix Ems Indonesia.

[11] Witanto, R., \& Solihin, H. H. (2016). Perancangan Sistem Informasi Penerimaan Siswa Baru Berbasis Web (Studi Kasus : Smp Plus Babussalam Bandung).

[12] Sidik, A. P., Andreswari, R., Fauzi, R., Industri, F. R., \& Telkom, U. (2019). Jurnal Tugas Akhir Universitas Telkom Futsal Kuy Platform Android Dengan Menggunakan Metode Waterfall.

[13] Nugraha, W., Syarif, M., \& Dharmawan, W. S. (2018). Penerapan Metode Sdlc Waterfall Dalam Sistem Informasi Inventori Barang Berbasis Desktop.

[14] Matera, D., Irwansyah, M. A., Sukamto, A. S., Studi, P., \& Universitas, I. (N.D.). Rancang Bangun Sistem Informasi Geografis Persebaran Lapangan Futsal Di Wilayah Pontianak Berbasis Web. 1-6.

[15] Mahdiana, D. (2016). Pengadaan Barang Dengan Metodologi Berorientasi Obyek : Studi Kasus Pt . Liga Indonesia. Jurnal Telematika, 3(2), 36-43. 